\title{
Valorisation of soy by-products as substrate for food ingredients containing L. casei through solid state fermentation
}

\author{
Adriana P. Castellanos Fuentes ${ }^{a, b}$, Carolina E. Genevois ${ }^{c}$, Silvia K. Flores ${ }^{a, b}$, Marina F. de \\ Escalada Pla ${ }^{\text {a,b,* }}$

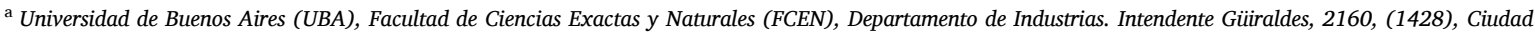 \\ Autónoma de Buenos Aires, Argentina \\ ${ }^{\mathrm{b}}$ CONICET - Universidad de Buenos Aires, Instituto de Tecnología de Alimentos y Procesos Químicos (ITAPROQ), Buenos Aires, Argentina \\ c CONICET - Universidad Nacional de Entre Ríos (UNER), Facultad de Bromatología, Gualeguaychú, Entre Ríos, Argentina
}

\section{A R T I C L E I N F O}

\section{Keywords:}

Soy by-products

L. casei

Box-behnken experimental design

\begin{abstract}
A B S T R A C T
Okara and soybean extruded-expelled meals (EEM) were used for preparation of ingredients containing probiotics applying a sustainable technology as solid state fermentation. The effect of three factors: particle size of okara or EEM, cheese whey and water content on the growth of $L$. casei, $\mathrm{pH}$ and total titratable acidity was studied. The particle size did not show significant effect, while addition of cheese whey $\left(0.32 \mathrm{~g} \mathrm{~g}^{-1}\right)$ maximised the cell growth. $L$. casei grew with the highest rate $\left(\mu_{\max }=7.3 \pm 0.9 \mathrm{~h}^{-1}\right)$ in the medium containing okara. The slowest rate was observed with EEM $\left(\mu_{\max }=1.9 \pm 0.3 \mathrm{~h}^{-1}\right)$. The subsequent unit operations applied for stabilising the ingredient reduced the $L$. casei count 1 and $0.6 \log$ cycles for okara and EEM respectively. The ingredients could be safety stored, at $25{ }^{\circ} \mathrm{C}$, rendering a probiotic count above $10^{6} \mathrm{CFU} \mathrm{g}{ }^{-1}$ at 63 and 42 days of storage for okara and EEM correspondingly.
\end{abstract}

\section{Introduction}

Okara is the residue generated during the manufacture of soy milk, it is susceptible to deterioration due to the high moisture content $(70-80 \%$ w.b.) and in addition, it retains many nutrients and is especially rich in dietary fibre, making it an adequate substrate, which can be used as a source for the production of functional ingredients (Vong \& Liu, 2016).

The soybean extruded-expelled meal (EEM), is the by-product of the soy oil extraction commonly used by small or medium sized Argentinian companies. Scarce technological advancements have been carried out to add value to the supply chain of the soybean EEM (Accoroni, Godoy, \& Reinheimer, 2020).

Fungal, bacterial and yeast fermentation of soy by-products were studied, mainly in okara, in order to obtain metabolites of technological interest and/or improve the nutritional quality of products (Vong \& Liu, 2016, 2019) while Quintana, Gerbino \& Gomez-Zavaglia, (2017) proposed the use of okara as culture media of Lactobacillus plantarum CIDCA in a submerged fermentation.
Probiotic-based products should contain at least $6 \log$ CFU.g ${ }^{-1}$ of viable cells at the moment of consumption to provide probiotic benefits (WHO/FAO, 2006). The scarce survival rate of probiotics during processing and storage is related to food matrix environmental stress such as the changes in $\mathrm{pH}$, oxygen toxicity and UV light exposure $(\mathrm{Xu}$, Gagné-Bourque, Dumont\& Jabaji, 2016). In this sense, encapsulation technique was widely applied to improve probiotic resistance to process and to extend the shelf life. For instance, microcapsules based on polysaccharides as well as protein/polysaccharides matrices were reported as alternatives for protection of $L$. casei, ATCC 393 (Li, Chen, Sun, Park, \& Cha, 2011; Xu, Gagné-Bourque, Dumont, \& Jabaji, 2016). In general, in encapsulation processes, probiotic should be produced in a considerable amount before being mixed with the corresponding biopolymeric solution. Both, probiotic suspension as well as biopolymeric solution should be prepared separately generating high water as well as energy consuming. Application of solid state fermentation (SSF) would provide a sustainable process saving drinking water and energy and with the maximum use of the vegetable source, since generating of new wastes is

Abbreviations: EEM, Extruded-expelled meal; SSF, Solid-state fermentation; CFU, Colony-forming units; WSF, Water soluble fraction; AIR, Alcohol insoluble residue.

* Corresponding author. Universidad de Buenos Aires (UBA), Facultad de Ciencias Exactas y Naturales (FCEN), Departamento de Industrias, Intendente Güiraldes, 2160, (1428), Ciudad Autónoma de Buenos Aires, Argentina.

E-mail address: marina@di.fcen.uba.ar (M.F. de Escalada Pla). 
drastically reduced. Vegetable by-products could provide part of the substrates for probiotic growth. In addition, the components from the same vegetable matrices could act as support for protection probiotic cells. In general, the main applications of SSF in the food area are related to improve the nutritional, physical, and flavour properties of food matrix. For instance, yeast and lactic acid bacteria have been used for fermenting wheat bran in solid state (Costa, Treichel, Kumar, \& Pandey, 2018). Nevertheless the best conditions for biomass growth can be not the best for the production of certain metabolites (Poletto, Polidoro, Zeni, \& da Silveira, 2017). In a previous work, it was observed that L. casei growth increased with the incubation period and decreased with inoculum size (Genevois, Flores, \& de Escalada Pla, 2016).

To the best of our knowledge, no reports related to the use of SSF for production of $L$. casei ATCC 393 immobilised in a partially digested vegetable matrix from soy by-products, okara or EEM were reported till the moment.

The aim of the present work was to profit okara and EEM as substrate for production of dehydrated functional ingredients containing probiotic microorganisms (L. casei ATCC ${ }^{\circledR} 393^{\mathrm{TM}}$ ) by means of SSF process. To reach this objective, the study of the medium characteristics formulated with soy by-product was performed. The effect of three factors: amount of cheese whey, amount of water and okara or EEM particle size on the $L$. casei growth, $\mathrm{pH}$ and total titratable acidity was analysed as indicator of the probiotics development through a response surface methodology, keeping constant inoculum size and fermentation time. In addition, one formulation was selected and characterised to define the specific growth rate in the new medium proposed. The effects of the subsequent unit operations for stabilising the final product, on the cell viability as well as shelf life at $25{ }^{\circ} \mathrm{C}$ storage were also analysed.

\section{Materials and methods}

\subsection{Okara preparation}

Soybeans (Glycine max) were purchased at a local supermarket, $500 \mathrm{~g}$ of soybean seeds were mixed with $500 \mathrm{~mL}$ of drinking water, soaked at $25^{\circ} \mathrm{C}$ for at least $18 \mathrm{~h}$. Subsequently, the seeds were washed and crushed (D-56 Moulinex, BA, Argentina), mixed with $2500 \mathrm{~mL}$ of water and heated with constant stirring to boiling $\left(\approx 100{ }^{\circ} \mathrm{C}\right)$ for $10 \mathrm{~min}$. After cooling, the mixture was filtered through a thin cloth and, pressed to separate the liquid (soy milk) from the residue (okara) (Li et al., 2014). The $\mathrm{pH}$ of the milk was measured $(\mathrm{pH} 6.41 \pm 0.07)$ and okara was dried at $60{ }^{\circ} \mathrm{C}$ for $6 \mathrm{~h}$. The dried product was milled (D-56 Moulinex, BA, Argentina) and sifted in a set of sieves (Zonytest, Rey Ronzoni, BA, Argentina); obtaining the following fractions in terms of average particle size: $630.00 ; 393.75$ and $175.50 \mu \mathrm{m}$. The different fractions were stored in vacuum bags at $-18{ }^{\circ} \mathrm{C}$ and thawed before use.

\subsection{EEM preparation}

EEM was kindly provided by R-Mix SRL (Urdinarrain, Entre Ríos, Argentina) and came from the soy oil extraction process without using solvents. EEM was milled and sieved in order to obtain different fractions as previously stated.

\subsection{Chemical characterisation of okara and EEM}

Moisture content was determined with a moisture analyser (Ohaus MB-45, NJ, USA). The protein and lipid contents were determined with Kjeldahl method 920.152 and 960.39 respectively (AOAC, 2006). The water soluble fraction (WSF) and the alcohol insoluble residue (AIR) as well as the dietary fibre composition (uronic acid, total non-cellulosic carbohydrate, cellulose and lignin contents) were analysed according to Genevois, Pieniazek, Messina, Flores \& de Escalada Pla (2019).

\subsection{Preparation and characterisation of the systems}

Fifteen systems were prepared in $50 \mathrm{~mL}$ Falcon ${ }^{\mathrm{TM}}$ centrifuge tubes (Corning Inc, NY, USA) with $1.0004 \pm 0.0004 \mathrm{~g}$ okara or EEM, the amount of distilled water and the partially demineralised cheese whey (Mageral, BA, Argentina), according to the proposed experimental design explained latter in material and method section (2.8) and detailed on Table 2. After sterilisation and cooling, the systems were inoculated with $0.1 \mathrm{~mL}$ of a $L$. casei (ATCC $₫ 393^{\mathrm{TM}}$ ) suspension $\approx 10^{4}$ $\mathrm{CFU} \mathrm{mL}{ }^{-1}$ in de Man, Rogosa y Sharpe (MRS) broth (Biokar Diagnostics, OI, France), and immediately they were incubated at $37^{\circ} \mathrm{C}$ for $24 \mathrm{~h}$, (Inquilab I-290, BA, Argentina) with constant agitation of $120 \mathrm{rpm}$ (Vicking, BA, Argentina), in order to improve the homogeneity of the cell population (Gervais \& Molin, 2003). Subsequently, systems were centrifuged at $167 \mathrm{~s}^{-1}$ for $10 \mathrm{~min}$ (Eppendorf, HH, Germany), pellets were washed with sterile distilled water and vacuum dried (Martin Christ Alpha 1-4 LSD, Germany) at $25{ }^{\circ} \mathrm{C}$ and 4.5 Pa for $36 \mathrm{~h}$. Dried powders were homogenised and the water activity $\left(\mathrm{a}_{\mathrm{w}}\right)$ was analysed with a hygrometer (Aqualab, WA, USA) at $20^{\circ} \mathrm{C}$. The viable $L$. casei was determined by plate counting using MRS agar followed by incubation at $37{ }^{\circ} \mathrm{C}$ for $72 \mathrm{~h}$ under aerobic conditions. The results were expressed as $\log \left(\mathrm{CFU} \mathrm{g}{ }^{-1}\right.$ d.b.) and $\Delta \mathrm{CFU}$ was also determined as the difference (log $\mathrm{N}_{24}-\log \mathrm{N}_{0}$ ), being $\mathrm{N}_{24}$, the cell count at $24 \mathrm{~h}$ incubation and $\mathrm{N}_{0}$ the initial cell count. Titratable acidity and $\mathrm{pH}$ were measured on the supernatants. Titratable acidity was determined with $\mathrm{NaOH}(0.01 \mathrm{~N})$ and phenolphthalein as an indicator. The results were expressed as the milliequivalent of lactic acid $\mathrm{g}^{-1}$ d.b. The $\mathrm{pH}$ was determined with a combined glass electrode $\mathrm{Ag}^{\circ} / \mathrm{AgCl}$ connected to a $\mathrm{pH}$ meter (Cole-Parmer, IL, USA).

\subsection{Process characterisation}

One system was selected from the experimental design analysis, for determining the growth kinetic of $L$. casei in these conditions. Briefly, $1.0 \mathrm{~g}$ of soy by-product (okara or EEM with particle size of $393.75 \mu \mathrm{m}$ ) was mixed with $0.32 \mathrm{~g}$ of cheese whey, $4.7 \mathrm{~mL}$ of water and inoculated with a cell suspension in order to achieve an initial count of $\approx 2.5 \times 10^{3}$ Colony-forming units (CFU). $\mathrm{g}^{-1}$ soy by-product. Cell counting was recording at different intervals for $48 \mathrm{~h}$. Registered data (20 points total), were referred to the initial counting, $\mathrm{N}_{0}$, and fitted to Gompertz model (Genevois et al., 2016).

$\operatorname{Ln}\left(\frac{N}{N_{0}}\right)=C \cdot \exp \left\{-\exp \left[\left(\frac{\mu_{\max }}{C}\right) \cdot(\operatorname{lag}-t)+1\right]\right\}$

Where, $\mathrm{N}$ is the number of viable bacteria of $L$. casei at a given time (h), CFU g ${ }^{-1}$; dry base (d.b.); $\mathrm{N}_{0}$ is the initial cell count (CFU g ${ }^{-1}$ d.b.); $\mathrm{C}$ is the maximum sustained logarithmic growth for $L$. casei; $\mu_{\max }$ is the maximum specific growth rate $\left(\mathrm{h}^{-1}\right)$; Lag is the adaptation phase $(\mathrm{h})$; $\mathrm{t}$ is the time of the incubation period (h). Growth curve was carried out in duplicate.

Based on the results of the experimental design and the growth kinetic, another two batches were performed in order to scale up the process and to analyse the effect of the stabilisation operations (washing, centrifugation and vacuum drying) as well as homogenization operations (milling and sieving), on the probiotic cell survival. The scaled up systems were prepared in $500 \mathrm{~mL}$ autoclavable screw cap glass flask (Schott ${ }^{\mathrm{TM}}$ Germany). Then, $10.0 \mathrm{~g}$ of sample (okara or EEM) with a particle size of $393.75 \mu \mathrm{m}$ were mixed with $47.4 \mathrm{~mL}$ of distilled water and $3.22 \mathrm{~g}$ of dehydrated cheese whey. After sterilisation, the mixtures were inoculated with $1 \mathrm{~mL}$ of a suspension containing $\approx 5 \times 10^{4} \mathrm{CFU}$ $\mathrm{mL}^{-1}$ of $L$. casei, incubated at $37^{\circ} \mathrm{C}$ for $24 \mathrm{~h}$ and stabilised as previously explained. Additionally, dried product was milled and sieved in order to homogenize the batches. At least, two batches were processed for each soy by-product, reporting average \pm standard deviation (SD) of the results. 


\subsection{Shelf-life study}

Stabilised ingredients were packed aseptically into low-density polyethylene bags $(80 \mu \mathrm{m})$ with an easy-to-close Ziploc ${ }^{\circledR}$ closing. The bags were stored in dark at $25^{\circ} \mathrm{C}$. Cell count was performed along stored period and data registered was fitted to a first order kinetic (eq. (2)):

$\frac{d N}{d t}=-k_{d} \cdot N$

Where $k_{d}$ represents the death rate of $L$. casei supported in the ingredient in the conditions here in assayed; $\mathrm{N}$ corresponds to cell count at different periods.

\subsection{Microstructure characterisation}

Scanning electronic microscopy (SEM, Supra ${ }^{\mathrm{TM}} 40$, Carl-Zeiss, Germany) were used to observe the microstructure of the vegetable matrices as well as to confirm the probiotic presence on them, after fermentation up to $20.000 \mathrm{X}$ magnifications. Dried samples were mounted on stubs and sputter-coated (Sputter 108, Cressington Scientific Instruments, UK) with a gold layer prior to imaging.

\subsection{Experimental design and statistical analysis}

A Box-Behnken design was used to study the effects of 3 factors: particle size $\left(\mathrm{X}_{1}\right)$, amount of water $\left(\mathrm{X}_{2}\right)$ and amount of cheese whey $\left(\mathrm{X}_{3}\right)$ in three levels for each factor (Table 2). Levels were established taking into account previous assays. Fermentation time as well as inoculum size were kept constant for all the systems, being stablished according previous results (Genevois et al., 2016). The experimental design for each soy by-product was carried out in a single block and the central points were performed in triplicate. The results were analysed using the response surface method (RSM) at the $95 \%$ confidence level. The experimental data were fitted to a second-order polynomial model:

$$
\begin{aligned}
y & =a_{0}+a_{1} X_{1}+a_{2} X_{2}+a_{3} X_{3}+a_{11} X_{1}^{2}+a_{22} X_{2}^{2}+a_{33} X_{3}^{2}+a_{12} X_{1} X_{2} \\
& +a_{13} X_{1} X_{3}+a_{23} X_{2} X_{3}+\varepsilon
\end{aligned}
$$

Where " $y$ " is the response function, $a_{i} a_{i i}$ and $a_{i j}$ are the coefficients of the linear, quadratic and interaction terms of the polynomial, $a_{0}$, independent term and $\varepsilon$ is the random error term. R-squared $\left(\mathrm{R}^{2}>79 \%\right)$, and a non-significant lack of fit ( $\mathrm{p}>0.05$ ) were used to inform the goodness of the model.

For non-linear regression, R-squared adjusted $\left(\mathrm{R}^{2}\right.$ adj $)$ greater than 90 and the Durbin Watson (DW) statistic higher than 1.0 were considered.

All determinations were performed at least in duplicate for each system. The complete design was repeated with a second batch of soybeans, observing the same tendencies.

The findings are informed on the basis of their average \pm standard deviation (SD). The statistical analysis of results was performed by use of the analysis of variance (ANOVA) for a level of significance $(\alpha)$ of 0.05 .

The experimental design, response surfaces, correlations, non-linear regressions and statistical analysis were carried out using the
Statgraphics Centurion XV (V 2.15.06, 2007, StatPoint, USA).

\section{Results and discussion}

\subsection{Chemical composition of soy by-products}

The composition of the two by-products presented differences as can be observed on Table 1. EEM contained more protein and fewer lipids than okara $(\mathrm{p}<0.05)$ and the values reported in the table are similar to those reported by Accoroni et al. (2020) for soy EEM from the same country. In addition, okara presented 1.6 more AIR, which represents cell wall material and simultaneously showed significant $(\mathrm{p}<0.05)$ lower WSF than EEM. AIR from okara was mainly composed by cellulose and non-cellulose polysaccharides. About half of non-cellulosic polysaccharides corresponded to galacturonic acid, being in accordance with previously reported by other authors (Porfiri et al., 2017). Taking into account the main components and AIR percentage (Table 1), the content of low molecular weight carbohydrates could be estimated by difference, resulting less than $\approx 4 \%$ for okara and $27 \%$ for EEM. Although soy grain used to obtain okara were not from the same source from EEM, it can be inferred that wet milling solubilised water soluble material reducing the remnant amount of sugars and concentrating the sample mainly in cell wall material in the okara sample (Table 1). Besides, as can be expected, oil extraction, reduced lipid content in EEM, concentrating the protein rate. In this process, lower loss of water soluble compounds might occur.

\subsection{Analysis of experimental design}

Table 2 details the levels tested for each independent variable: particle size of soy by-products, water content and cheese whey; the values obtained for each response variable were also presented. $L$. Casei grew in all systems tested as can be observed through the positive value for $\Delta$ CFU (Table 2). Regarding independent variables, in general, coefficients associated with particle size were not significant for any response variable. Therefore, it can be considered that particle size did not affect the fermentation process in the condition assayed in the present design; and then the response surfaces of cell counting, cell growth as $\triangle \mathrm{CFU}$, acidity and $\mathrm{pH}$ as a function of amount of cheese whey and water content were plotted at the central point of particle size $(\approx 394$ $\mu \mathrm{m})$ (Fig. 1). It can be observed on Panels A, B, C, D, that higher cheese whey rendered higher $L$. casei growth and cell count. With respect to the linear coefficients for cell count and $\triangle \mathrm{CFU}$, those of EEM resulted more than double than that of okara (Fig. 1 A, B, C, D). It might be interpreted as a better $L$. casei response to growth when systems were prepared with EEM. On Table 1 it could be observed a higher WSF content for EEM substrate, suggesting that more nutrients were solubilised in water leading better conditions for the probiotic growing. In addition, these response surfaces presented a negative curvature being more pronounced for EEM plots, although the coefficient for the quadratic terms resulted not significant ( $\mathrm{p}=0.051$ ). Cheese whey also affected $\mathrm{pH}$ and titratable acidity. As can be observed titratable acidity increased with higher cheese whey and consequently pH decreased (Fig. 1, Panels E, F,

Table 1

\begin{tabular}{|c|c|c|c|c|c|c|c|c|c|}
\hline & Protein $^{\mathrm{a}}$ & Lipid $^{\mathrm{a}}$ & Moisture $^{\mathrm{b}}$ & $\mathrm{WSF}^{\mathrm{a}}$ & $\mathrm{AIR}^{\mathrm{a}}$ & Celulose $^{c}$ & $\operatorname{Lignin}^{c}$ & HC no celulosic ${ }^{c}$ & Uronic Acid $^{c}$ \\
\hline Okara & $39 .^{\mathrm{c}} \pm 0.5^{\mathrm{a}}$ & $16 \pm 2^{\mathrm{a}}$ & $4.1 \pm 0.6^{\mathrm{a}}$ & $6.7 \pm 0.4^{\mathrm{a}}$ & $79 \pm 4^{\mathrm{a}}$ & $18.14 \pm 0.04^{\mathrm{a}}$ & $1.9 \pm 0.8^{\mathrm{a}}$ & $31 \pm 5^{\mathrm{a}}$ & $13 \pm 4^{\mathrm{a}}$ \\
\hline Expeller & $43.0 \pm 0.2^{\mathrm{b}}$ & $8.7 \pm 0.3^{b}$ & $5.9 \pm 0.3^{\mathrm{a}}$ & $19 \pm 1^{\mathrm{b}}$ & $49 \pm 2^{\mathrm{b}}$ & $18 \pm 3^{\mathrm{a}}$ & $3 \pm 1^{\mathrm{a}}$ & $22 \pm 6^{\mathrm{a}}$ & $10 \pm 2^{\mathrm{a}}$ \\
\hline
\end{tabular}

Chemical composition of soy by-products, okara and expeller.

WSF: water soluble fraction.

AIR: Alcohol insoluble residue.

HC no cellulosic: total non-cellulosic carbohydrates.

a $\mathrm{g} / 100 \mathrm{~g}$ sample d.b.

b $\mathrm{g} / 100 \mathrm{~g}$ sample w.b.

c $\mathrm{g} / 100 \mathrm{~g}$ AIR 


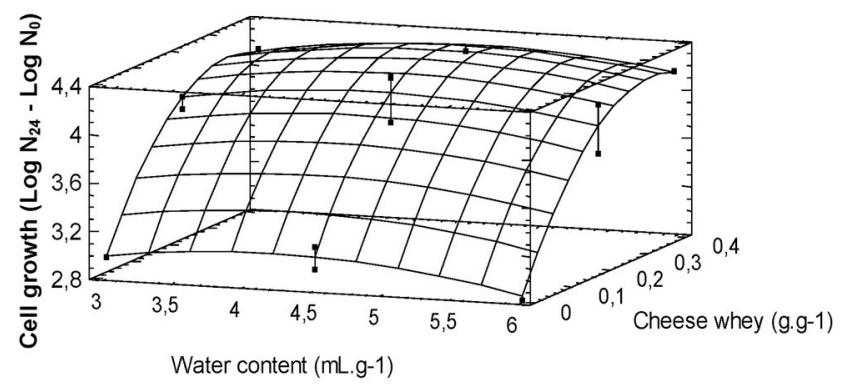

Cell growth, $\Delta \mathrm{CFU}=2.45655-0.001^{*} \mathrm{X}_{1}+0.44^{*} \mathrm{X}_{2}+6.81^{*} \mathrm{X}_{3}$ $-6.28575 E-7^{\star} X_{1}{ }^{2}+0.0004^{*} X_{1}{ }^{*} X_{2}+0.0009^{*} X_{1}{ }^{*} X_{3}-0.07^{*} X_{2}{ }^{2}+$ $0.15^{*} X_{2}{ }^{*} X_{3}-11.95^{*} X_{3}{ }^{2}, R^{2}=96.84 \%$, lack of fit: 0.8546

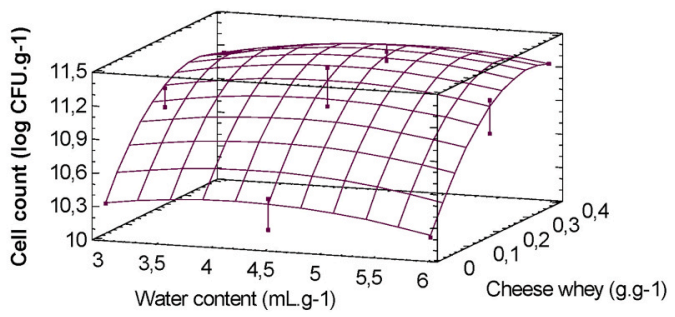

Cell count $=9.76623-0.0004^{*} X_{1}+0.38^{*} X_{2}+4.98^{*} X_{3}-1.9 E-$ $6^{*} X_{1}{ }^{2}+0.00033^{*} X_{1}{ }^{*} X_{2}+0.0011^{*} X_{1}{ }^{*} X_{3}-9.73^{*} X_{2}{ }^{2}+$ $0.18^{*} X_{2}{ }^{*} X_{3}-6.85^{*} X_{3}{ }^{2}, R^{2}=95.49 \%$, lack of fit: 0.8553

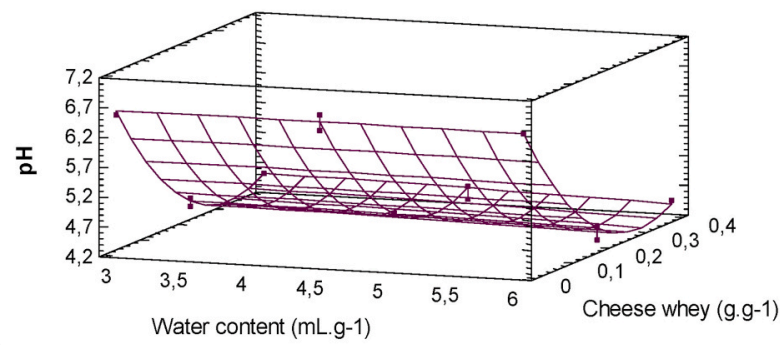

$\mathrm{pH}=6.48+0.0005^{*} X_{1}+0.07^{*} X_{2}-14.85^{*} X_{3}-9.4 \mathrm{E}-7^{*} X_{1}{ }^{2}+$ $0.00006{ }^{*} X_{1}{ }^{*} X_{2}+0.0003^{*} X_{1}{ }^{*} X_{3}-0.006 * X_{2}{ }^{2}-0.11{ }^{*} X_{2}{ }^{*} X_{3}+$ $24.75^{*} X_{3}{ }^{2}, R^{2}=99.84 \%$, lack of fit: 0.063

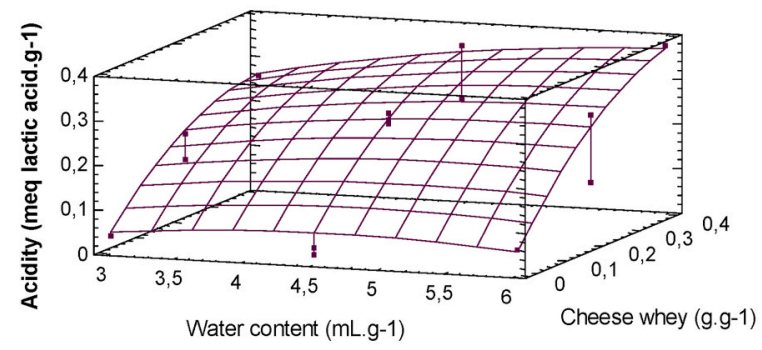

Acidity $=-0.3373+0.00085^{\star} X_{1}+0.11^{*} X_{2}+1.04^{\star} X_{3}-7.9 E-$ $7^{\star} X_{1}{ }^{2}+0.00007^{*} X_{1}{ }^{*} X_{2}-0.0006^{*} X_{1}{ }^{*} X_{3}-0.009^{*} X_{2}{ }^{2}+$ $0.082 * X_{2}{ }^{*} X_{3}-1.297^{*} X^{2}{ }^{2}, R^{2}=99.37 \%$, lack of fit: 0.350

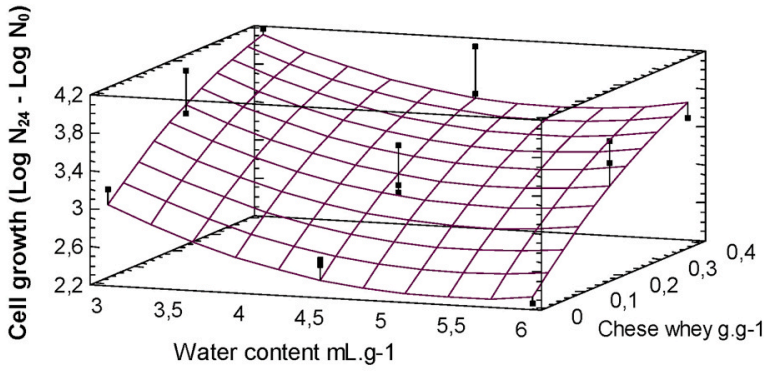

Cell growth, $\Delta$ CFU $=7.8343-0.006^{*} X_{1}-1.65^{\star} X_{2}+2.72^{\star} X_{3}$ $+4.3 \mathrm{E}-6^{\star} X_{1}{ }^{2}+0.0005^{\star} X_{1}{ }^{*} X_{2}+0.0023^{\star} X_{1}{ }^{*} X_{3}+0.14^{*} X_{2}{ }^{2}+$ $0.215^{*} X_{2}{ }^{*} X_{3}-3.84^{*} X_{3}{ }^{2}, R^{2}=93.28 \%$, lack of fit: 0.5614

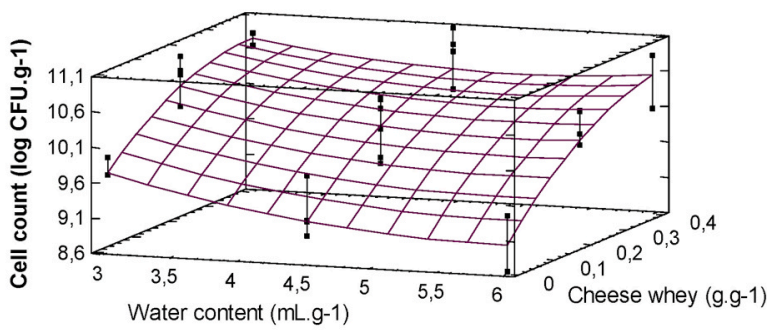

Cell count $=13.31-0.005^{\star} X_{1}-1.07^{*} X_{2}+2.45^{\star} X_{3}-3.25 E-$ $6^{*} X_{1}{ }^{2}+0.00032^{*} X_{1}{ }^{*} X_{2}+0.0043^{*} X_{1}{ }^{*} X_{3}+0.08^{*} X_{2}{ }^{2}+$ $0.41^{*} X_{2}{ }^{*} X_{3}-6.85^{*} X_{3}{ }^{2}, R^{2}=79.81 \%$, lack of fit: 0.8609

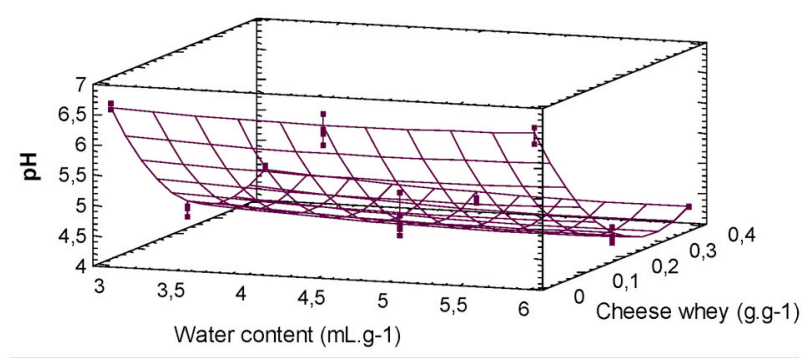

$\mathrm{pH}=6.92+0.0016^{*} X_{1}-0.32^{*} X_{2}-15^{*} X_{3}-2.0 \mathrm{E}-6^{*} X_{1}{ }^{2}+$ $0.000018^{*} X_{1}{ }^{*} X_{2}+0.00011^{*} X_{1}{ }^{*} X_{3}+0.03^{*} X_{2}{ }^{2}-0.16^{*} X_{2}{ }^{*} X_{3}+$ $25.84^{*} X_{3}^{2}, R^{2}=97.88 \%$, lack of fit: 0.8730

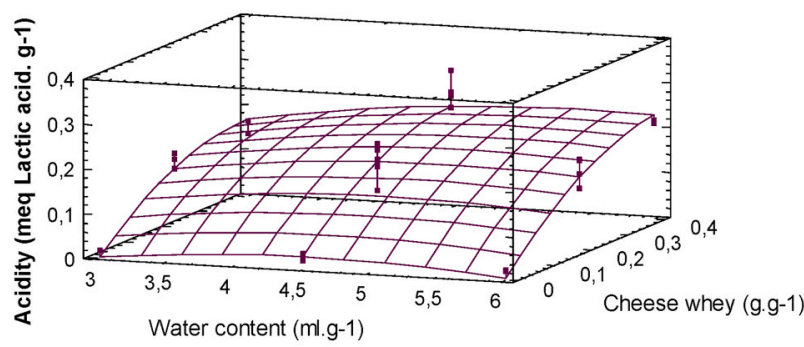

Acidity $=-0.1843-0.00015^{*} X_{1}+0.11^{*} X_{2}+0.81 * X_{3}+3.0 E-$ $7^{*} X_{1}{ }^{2}+0.000015^{*} X_{1}{ }^{*} X_{2}-0.00023^{*} X_{1}{ }^{*} X_{3}-0.011^{*} X_{2}{ }^{2}+$ $0.05^{*} X_{2}{ }^{*} X_{3}-1.11^{*} X_{3}{ }^{2}, R^{2}=92.08 \%$, lack of fit: 0.1230

Fig. 1. Response surfaces of cell growth as $\triangle \mathrm{CFU}$ (A; B), cell count (C; D), pH (E; F) and acidity (G; H) as a function of water and cheese whey content, keeping constant particle size at the central point $(\approx 394 \mu \mathrm{m})$. A, C, E and G corresponds to EEM systems; B, D, F, H corresponds to okara systems. In boxes the corresponding second-order polynomial equations and fit goodness parameters. Regression coefficients highlighted in bold have a significant ( $p<0.05)$ effect on the response variable. $\mathrm{X}_{1}$ : particle size $(\mu \mathrm{m}) ; \mathrm{X}_{2}$ : amount of water $\left(\mathrm{mL} \cdot \mathrm{g}^{-1}\right) ; \mathrm{X}_{3}$ : amount of cheese whey $\left(\mathrm{g} \cdot \mathrm{g}^{-1}\right)$. 
G, H). Water content affected significantly only the cell count and titratable acidity of okara systems. While in EEM systems, linear and quadratic coefficients for water variable were significant for $\mathrm{pH}$ and acidity response, but at least one order of magnitude lower than those of whey. Besides, positive and significant correlation between titratable acidity and cell growth $(\Delta \mathrm{CFU})$ could be detected $(\mathrm{p}<0.01)$. Pearson product moment coefficient was 0.6757 and 0.8232 for okara and EEM respectively, indicating that lactic acid production was partially associated to the cell growth. The homofermentative $L A B$ requirement of energy for growth and maintenance, is obtained by producing lactic acid, therefore this last one is not directly associated with the synthesis of new cells (Sharma \& Mishra, 2014).

It has been reported that $\mathrm{pH}$ is the factor that most influences cell viability in products such as yogurt (Champagne, Ross, Saarela, Hansen, \& Charalampopoulos, 2011). However, according to the results of our work, a decrease in $\mathrm{pH}$ to values around 4.0 did not have a negative influence on the survival of the probiotic (Table 2), possibly due to the protective effect provided by the vegetable matrix Genevois et al. (2016).

According to the prediction model, the conditions that would maximize cell count are $417 \mu \mathrm{m}$ in particle size; $4.7 \mathrm{~mL}$ of water. $\mathrm{g}^{-1}$ of dry EEM and $0.32 \mathrm{~g}$ of cheese whey. $\mathrm{g}^{-1}$ dry EEM. It should be noted that these conditions would approximate to those tested at the central point of the proposed design. As observed in Table 2, $11.4 \pm 0.2 \log$ CFU.g ${ }^{-1}$ was obtained experimentally for the central point of the EEM design, which would correspond to the value statistical estimated, 11.4. In the case of okara design, particle sizes of $157.50 \mu \mathrm{m}$, water contents of 3.0 $\mathrm{mL} \mathrm{g}^{-1}$ of okara; and cheese whey amounts $0.31 \mathrm{~g} \mathrm{~g}^{-1}$ of okara, were the conditions that would maximize cell count resulting $10.94 \log \mathrm{CFU} . \mathrm{g}^{-1}$, value that was statically estimated. It can be observed that systems 6,7 and 11 tested in the experimental design are those that presented the highest cell counts, regardless of the particle size used (Table 2). This is because the latter factor did not have a significant effect on this response, while the amount of water and cheese whey of these systems are in accordance with those statistically estimated.

\subsection{Growth kinetic of L. casei}

The knowledge of kinetic behaviour of microorganisms when a new medium was proposed is essential for the industrial process design and scale up (Rezvani, Ardestani, \& Najafpour, 2017). Fig. 2 shows the growth curves obtained for the systems selected. No lag or latency phase, neither death phase, could be observed in the conditions here in assayed. This fact let infer that this probiotic strain presented an immediate adaptation to the medium formulated with both soy by-products and, besides, could remain stable without losing viability at least over $48 \mathrm{~h}$.

Nevertheless, the growth profile differed according to soy byproduct. Steeper slope for the exponential phase of growth was obtained with okara as substrate reaching the stationary phase at $\approx 14 \mathrm{~h}$ from which remain stable till the end of the assay, $48 \mathrm{~h}$ (Fig. 2). However, $L$. casei could growth slower but steadily when EEM was used as substrate. Experimental data fitted adequately $\left(\mathrm{R}^{2}{ }_{\text {adj }}>0.918\right.$; $\left.\mathrm{DW}>1.9\right)$

Table 2

Experimental and coded values of the independent variables and responses obtained from the Box-Behnken design.

\begin{tabular}{|c|c|c|c|c|c|c|c|c|c|c|c|}
\hline \multirow{5}{*}{ Systems } & \multicolumn{3}{|c|}{ Independent Variables } & \multicolumn{4}{|c|}{ Response Variables from Okara } & \multicolumn{4}{|c|}{ Response Variables from EEM } \\
\hline & $\begin{array}{l}\text { Particle } \\
\text { size }\end{array}$ & Water & $\begin{array}{l}\text { Cheese } \\
\text { Whey }\end{array}$ & L. casei count & $\mathrm{pH}$ & Titratable Acidity & $\triangle \mathrm{CFU}^{\mathrm{b}}$ & $\begin{array}{l}\text { L. casei } \\
\text { bount }\end{array}$ & $\mathrm{pH}$ & Titratable Acidity & $\triangle \mathrm{CFU}^{\mathrm{b}}$ \\
\hline & $(\mu \mathrm{m})$ & $\left(\mathrm{mL}^{\mathrm{b}}\right.$ & (g) & \multirow{3}{*}{$\begin{array}{l}\log (\mathrm{CFU} \\
\left.\mathrm{g}^{-1}\right)\end{array}$} & & \multirow{3}{*}{$\begin{array}{l}\text { (meq lactic acid } \\
\mathrm{g}^{-1} \text { ) }\end{array}$} & & \multirow{3}{*}{$\begin{array}{l}\log (\mathrm{CFU} \\
\left.\mathrm{g}^{-1}\right)\end{array}$} & & \multirow{3}{*}{$\begin{array}{l}\text { (meq lactic acid } \\
\mathrm{g}^{-1} \text { ) }\end{array}$} & \\
\hline & \multicolumn{3}{|c|}{$\overline{\text { Coded and }}$ uncoded levels ${ }^{\text {a }}$} & & & & & & & & \\
\hline & $\mathrm{a}_{1}$ & $\mathrm{X}_{2}$ & $\mathrm{X}_{3}$ & & & & & & & & \\
\hline $1^{c}$ & $393.75\left(0^{c}\right.$ & $4.5(0)$ & $0.2(0)$ & $\begin{array}{l}9.677 \pm \\
0.009\end{array}$ & $\begin{array}{l}4.36 \pm \\
0.07\end{array}$ & $0.17 \pm 0.01$ & $\begin{array}{l}3.0 \pm \\
0.1\end{array}$ & $11.4 \pm 0.2$ & $\begin{array}{l}4.5 \pm \\
0.3\end{array}$ & $0.3 \pm 0.1$ & $4.3 \pm 0.2$ \\
\hline $2^{c}$ & $393.75\left(0^{c}\right.$ & $4.5(0)$ & $0.2(0)$ & $9.58 \pm 0.08$ & $\begin{array}{l}4.48 \pm \\
0.07\end{array}$ & $0.161 \pm 0.004$ & $\begin{array}{l}2.9 \pm \\
0.1\end{array}$ & $11.4 \pm 0.2$ & $\begin{array}{l}4.6 \pm \\
0.3\end{array}$ & $0.25 \pm 0.03$ & $4.3 \pm 0.2$ \\
\hline $3^{c}$ & $393.75\left(0^{c}\right.$ & $4.5(0)$ & $0.2(0)$ & $10.1 \pm 0.1$ & $\begin{array}{l}4.26 \pm \\
0.07\end{array}$ & $0.20 \pm 0.03$ & $\begin{array}{l}3.4 \pm \\
0.1\end{array}$ & $11.0 \pm 0.2$ & $\begin{array}{l}4.6 \pm \\
0.3\end{array}$ & $0.26 \pm 0.01$ & $3.9 \pm 0.2$ \\
\hline 4 & $393.75(0)$ & $6.0(1)$ & $0.4(1)$ & $10.1 \pm 0.1$ & $\begin{array}{l}4.31 \pm \\
0.07\end{array}$ & $0.22 \pm 0.04$ & $\begin{array}{l}3.5 \pm \\
0.1\end{array}$ & $11.2 \pm 0.2$ & $\begin{array}{l}4.5 \pm \\
0.3\end{array}$ & $0.38 \pm 0.04$ & $4.2 \pm 0.2$ \\
\hline 5 & $630.00(1)$ & $\begin{array}{l}3.0 \\
(-1)\end{array}$ & $0.2(0)$ & $10.2 \pm 0.3$ & $\begin{array}{l}4.42 \pm \\
0.07\end{array}$ & $0.151 \pm 0.004$ & $\begin{array}{l}3.6 \pm \\
0.3\end{array}$ & $11.0 \pm 0.2$ & $\begin{array}{l}4.5 \pm \\
0.3\end{array}$ & $0.142 \pm 0.005$ & $3.9 \pm 0.2$ \\
\hline 6 & $393.75(0)$ & $\begin{array}{l}3.0 \\
(-1)\end{array}$ & $0.4(1)$ & $\begin{array}{l}10.844 \pm \\
0.008\end{array}$ & $\begin{array}{l}4.59 \pm \\
0.08\end{array}$ & $0.14 \pm 0.02$ & $\begin{array}{l}4.2 \pm \\
0.1\end{array}$ & $11.2 \pm 0.2$ & $\begin{array}{l}4.6 \pm \\
0.3\end{array}$ & $0.26 \pm 0.03$ & $4.2 \pm 0.2$ \\
\hline 7 & $630.00(1)$ & $4.5(0)$ & $0.4(1)$ & $\begin{array}{l}10.743 \pm \\
0.008\end{array}$ & $\begin{array}{l}4.26 \pm \\
0.07\end{array}$ & $0.26 \pm 0.03$ & $\begin{array}{l}4.1 \pm \\
0.1\end{array}$ & $11.2 \pm 0.2$ & $\begin{array}{l}4.3 \pm \\
0.3\end{array}$ & $0.23 \pm 0.01$ & $4.2 \pm 0.2$ \\
\hline 8 & $\begin{array}{l}157.50 \\
(-1)\end{array}$ & $4.5(0)$ & $0.4(1)$ & $10.2 \pm 0.3$ & $\begin{array}{l}4.24 \pm \\
0.07\end{array}$ & $0.31 \pm 0.02$ & $\begin{array}{l}3.6 \pm \\
0.3\end{array}$ & $11.3 \pm 0.2$ & $\begin{array}{l}4.5 \pm \\
0.3\end{array}$ & $0.35 \pm 0.03$ & $4.2 \pm 0.2$ \\
\hline 9 & $630.00(1)$ & $4.5(0)$ & $0.0(-1)$ & $9.2 \pm 0.3$ & $6.2 \pm 0.1$ & $0.035 \pm 0.005$ & $\begin{array}{l}2.5 \pm \\
0.3\end{array}$ & $10.3 \pm 0.1$ & $\begin{array}{l}6.5 \pm \\
0.5\end{array}$ & $0.021 \pm 0.001$ & $3.1 \pm 0.1$ \\
\hline 10 & $393.75(0)$ & $\begin{array}{l}3.0 \\
(-1)\end{array}$ & $0.0(-1)$ & $9.7 \pm 0.6$ & $6.6 \pm 0.1$ & $0.016 \pm 0.002$ & $\begin{array}{l}3.0 \pm \\
0.6\end{array}$ & $\begin{array}{l}10.323 \pm \\
0.001\end{array}$ & $\begin{array}{l}6.6 \pm \\
0.5\end{array}$ & $0.040 \pm 0.001$ & $\begin{array}{l}3.15 \pm \\
0.01\end{array}$ \\
\hline 11 & $\begin{array}{l}157.50 \\
(-1)\end{array}$ & $\begin{array}{l}3.0 \\
(-1)\end{array}$ & $0.2(0)$ & $\begin{array}{l}10.741 \pm \\
0.008\end{array}$ & $\begin{array}{l}4.28 \pm \\
0.07\end{array}$ & $0.16 \pm 0.02$ & $\begin{array}{l}4.1 \pm \\
0.1\end{array}$ & $11.1 \pm 0.2$ & $\begin{array}{l}4.7 \pm \\
0.3\end{array}$ & $0.20 \pm 0.01$ & $4.0 \pm 0.2$ \\
\hline 12 & $630.00(1)$ & $6.0(1)$ & $0.2(0)$ & $10.2 \pm 0.4$ & $\begin{array}{l}4.25 \pm \\
0.07\end{array}$ & $0.20 \pm 0.01$ & $\begin{array}{l}3.5 \pm \\
0.4\end{array}$ & $11.8 \pm 0.2$ & $\begin{array}{l}4.3 \pm \\
0.3\end{array}$ & $0.140 \pm 0.005$ & $4.2 \pm 0.2$ \\
\hline 13 & $393.75(0)$ & $6.0(1)$ & $0.0(-1)$ & $8.6 \pm 0.8$ & $6.6 \pm 0.1$ & $0.020 \pm 0.001$ & $\begin{array}{l}1.9 \pm \\
0.8\end{array}$ & $10.23 \pm 0.05$ & $\begin{array}{l}6.6 \pm \\
0.5\end{array}$ & $0.058 \pm 0.001$ & $\begin{array}{l}3.00 \pm \\
0.05\end{array}$ \\
\hline 14 & $\begin{array}{l}157.50 \\
(-1)\end{array}$ & $4.5(0)$ & $0.0(-1)$ & $9.2 \pm 0.3$ & $6.4 \pm 0.1$ & $0.034 \pm 0.008$ & $\begin{array}{l}2.5 \pm \\
0.3\end{array}$ & $10.51 \pm 0.09$ & $\begin{array}{l}6.7 \pm \\
0.5\end{array}$ & $0.037 \pm 0.004$ & $3.3 \pm 0.1$ \\
\hline 15 & $\begin{array}{l}157.50 \\
(-1)\end{array}$ & $6.0(1)$ & $0.2(0)$ & $10.0 \pm 0.2$ & $\begin{array}{l}4.22 \pm \\
0.07\end{array}$ & $0.17 \pm 0.04$ & $\begin{array}{l}3.4 \pm \\
0.2\end{array}$ & $10.9 \pm 0.2$ & $\begin{array}{l}4.5 \pm \\
0.3\end{array}$ & $0.29 \pm 0.01$ & $3.8 \pm 0.2$ \\
\hline
\end{tabular}

$\mathrm{X}_{1}$ particle size, $\mathrm{X}_{2}$ water content, $\mathrm{X}_{3}$ cheese whey content.

a Coded values are indicated in brackets.

b $\triangle \mathrm{CFU}=\log \mathrm{CFU} \mathrm{g}{ }^{-1}(24 \mathrm{~h})-\log \mathrm{CFU} \mathrm{g}{ }^{-1}(0 \mathrm{~h})$.

c Central points from experimental design. 


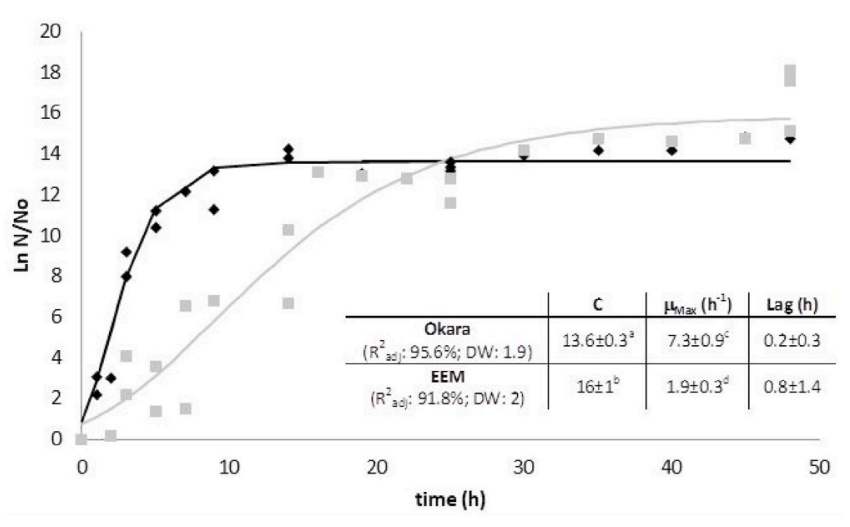

Fig. 2. Growth curve of $L$. casei in okara based medium (black rhomboid) and EEM based medium (grey squares). Solid lines represent the respective fit to Gompertz model. The table inserted details the characteristic Gompertz parameters. Different letters denote significant difference $(\mathrm{p}<0.05)$.

to Gompertz model. Alvarez, Aguirre-Ezkauriatza, Ramírez-Medrano, and Rodríguez-Sánchez (2010) also showed a steeper exponential phase with an inoculum decreasing of Lactobacillus casei var. rhamnosus, in a submerged condition with a deproteinised whey medium. In the present work, the same initial inoculum charge $\approx 10^{3} \mathrm{CFU} \mathrm{mL}^{-1}$ was maintained for both soy by-products, therefore the steeper slope observed in okara, might be related to a better nutrient accessibility for inoculated probiotics cells. In this sense, the accessibility of components in a SSF could depend not only on chemical composition (Table 1) but also the substrate microstructure (Couto \& Sanromán, 2006). As can be observed on Fig. 3A, okara presents a more fibrous microstructure; while in the case of EEM a more particulate and compact structure is shown on Fig. 3C. Despite water soluble compounds, water access to other matrix components as well as access of $L$. casei cells inside vegetable structure, could be better in the case of okara mainly in the first step of fermentation (exponential growth phase). Consequently, this effect could not be registered during the experimental design, since cell count was measured after $24 \mathrm{~h}$ incubation, far from exponential phase (Fig. 2). The maximum sustained logarithmic growth of $L$. casei, $C$, as well as the maximum specific growth rate, $\mu_{\max }$, could be calculated; showing significant differences between $(\mathrm{p}<0.05)$ soy by-products: $13.6 \pm 0.3$ and $7.3 \pm 0.9 \mathrm{~h}^{-1}$ for okara and $16 \pm 1$ and $1.9 \pm 0.3 \mathrm{~h}^{-1}$ for EEM, respectively. Sharma and Mishra (2014) assayed Lactobacillus plantarum NCDC 414 for fermentation of vegetable juices. They reported that differences in substrates strongly affected the growth curve profile. The parameter " $C$ " decreased and the specific growth rate " $\mu_{\max }$ " increased in modified MRS broth and, in addition, a significant reduction in the lag phase were observed when compared with vegetable juice as substrate. Rezvani et al. (2017) studied the growth kinetic of five species of Lactobacilli in batch submerged medium of deproteinated whey reporting $\approx$ $6 \mathrm{~h}$ lag phase for almost all strain tested. Alvarez et al. (2010), who also used deproteinated whey as carbon source, suggested that the extended lag phases observed (5-10 h) were due, in part, to the time required for L. casei inoculum to adequately adapt its enzymatic machinery for lactose hydrolysis. With respect to maximum specific growth rate $\left(\mu_{\max }\right)$, it must be highlighted that the value determined herein, were one order higher than that reported by Sharma and Mishra (2014) for Lactobacillus plantarum in vegetable juice. This result is relevant since $\mu_{\max }$ is the response that defines the fermentation process. The absence of lag phase as well as accelerated growth phase presented in the systems herein analysed let conclude that medium prepared with both soy by-products provided favourable conditions for $L$. casei ATCC 393 development.

\subsection{Scale up of ingredient production}

Taking into account the previous results, the first scale change was carried out. The same system selected to study the growth kinetic was performed with one order of magnitude higher. After washing, centrifuging, drying, milling and sieving, the calculated yield was $88 \pm 15 \%$ $\mathrm{w} / \mathrm{w}$ of the ingredient based on okara. With regards to EEM, the yield
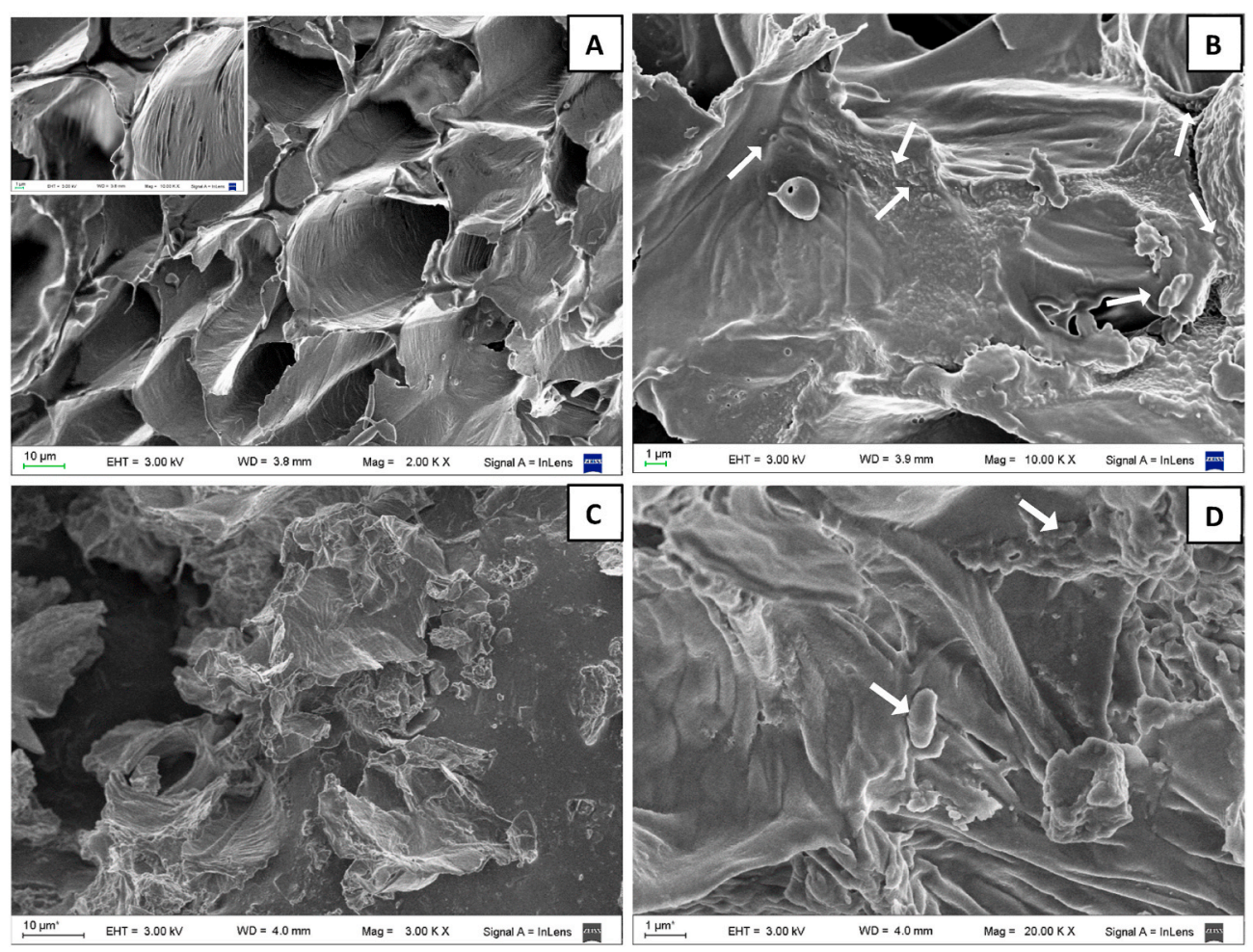

Fig. 3. Scanning electronic microscopy of okara (A and B) and EEM (C and D) systems. Control soy by-product matrices (without $L$. casei) (A and C). Magnification: 2,000X for A and B; 3,000X for C and 20,000X for D; 10,000X for the inserted picture in A panel. Arrows indicate L. casei cells in the ingredients (B and D). 
was $57 \pm 2 \% \mathrm{w} / \mathrm{w} \mathrm{g}$ of the ingredient. Okara matrix contained lower WSF (Table 2) and for this reason higher yield was obtained despite of the fermentation and stabilisation processes. In the case of EEM, even though probiotic biomass was generated, more water soluble compounds could be lost in the process, mainly in the washing step. As discussed previously, no stationary phase was registered during the $48 \mathrm{~h}$ of the growing curve of EEM system. Therefore, it might infer that in the scaled batch fermented $24 \mathrm{~h}$, some water soluble nutrients remained without being metabolised and consequently lost with the further washing. On the other hand, $\ln \left(\mathrm{N} / \mathrm{N}_{0}\right)$ attained when fermentation was completed, resulted 11.5 and 12.93 for okara and EEM respectively, being in concordance with the values shown in the corresponding growing curve. The subsequent stabilising process: washing, centrifuging, drying, milling and sieving, reduced the cell count around 1.0 and 0.6 orders of magnitude for okara and EEM systems respectively.

At the end of drying process the ingredients presented $\mathrm{a}_{\mathrm{w}}$ of $0.19 \pm$ 0.08 and $0.13 \pm 0.02$ for okara and EEM respectively. After homogenization, packed and storage an increased in $\mathrm{a}_{\mathrm{w}}$ was observed, being at the end of storage $0.485 \pm 0.003$ and $0.415 \pm 0.004$ for okara and EEM respectively. Although moisture content increased, it was not significant ( $p>0.05$ ), achieving, at the end of storage, $5.7 \pm 0.7 \%$ w.b., for okara based ingredient and $5.4 \pm 0.5 \%$ w.b. for EEM. Packaging process could be improved in order to avoid $\mathrm{a}_{\mathrm{w}}$ increasing during storage. Nevertheless, these conditions were still in the range for conferring stability from microbiological point of view (Tymczyszyn et al., 2008). In this context, shelf life of ingredients stored at $25{ }^{\circ} \mathrm{C}$ was determined. The criterion adopted was to maintain probiotic count above $10^{6} \mathrm{CFU} \mathrm{g}^{-1}$, according to the international recommendations. Cell decreases $\left(\mathrm{Ln} \mathrm{N} / \mathrm{N}_{0}\right)$ during storage at $25{ }^{\circ} \mathrm{C}$ are shown on Fig. 4. L. casei supported on okara remained stable for 40 days showing slight but significant reduction thenceforth, achieving a cell count of $7.5 \pm 0.4 \log$ CFU. $g^{-1}$ at 63 days of storage. In the case of EEM, a tendency to lower counts could be perceived till 35 days and, afterward, it was observed a significant $(\mathrm{p}<$ 0.05 ) reduction in cell population until end of storage, showing $6.1 \pm$ $0.6 \log$ CFU.g ${ }^{-1}$ at 42 days of storage. The first order kinetic fitted adequately to experimental data. The slope represents the $L$. casei death rate $\left(\mathrm{k}_{\mathrm{d}}\right)$ during storage in the condition assayed, being $0.121 \pm 0.005$ day $^{-1}\left(R^{2}: 0.9902\right)$ for EEM and $0.08 \pm 0.01$ day $^{-1}\left(R^{2}: 0.9138\right)$ for okara (Fig. 4). The slower decay in the cell viability presented in the okara ingredient permit to conclude that this matrix proved to be a better support than EEM for stabilising the probiotic during storage. Higher fibre and lipid content in okara matrix (Table 2) could explain its better performance as substrate and support for the probiotic cells (Genevois et al., 2016; Quintana, Gerbino, \& Gómez-Zavaglia, 2017). L. casei cells were also marked with arrows on Fig. 3B and D. It is important to remark that both soy by-products storage at $25{ }^{\circ} \mathrm{C}$, presented a probiotic count above $10^{6} \mathrm{CFU} \mathrm{g}^{-1}$, for 63 days in the case of okara ingredient, while EEM ingredient was stable stored at $25^{\circ} \mathrm{C}$ till 42 days. This result is relevant because no refrigeration is needed for storage the novel ingredients proposed, and therefore costs for the cold chain are drastically reduced. For instance, Xu et al. (2016) encapsulated Lactobacillus casei ATCC 393 cells in pea protein isolate-alginate hydrogel capsules. The protective effect of the protein-polysaccharide capsules could be proved at freeze temperature $\left(-15^{\circ} \mathrm{C}\right)$ while at $4{ }^{\circ} \mathrm{C}$ and $22{ }^{\circ} \mathrm{C}$ a significant decay was registered from 14 to 7 storage days respectively.

\section{Conclusions}

By-products from soy milk processing, okara, as well from oil extraction, EEM, were used for first time as substrate for preparing food ingredients containing L. casei ATCC 393 through SSF technology.

The particle size of the soy by-products had no significant effect on any of the response variables associated to cell growth or metabolism (Cell growth, L. casei counting, $\mathrm{pH}$ and acidity). On the other hand, cheese whey was the factor with the greatest effects in all the variables

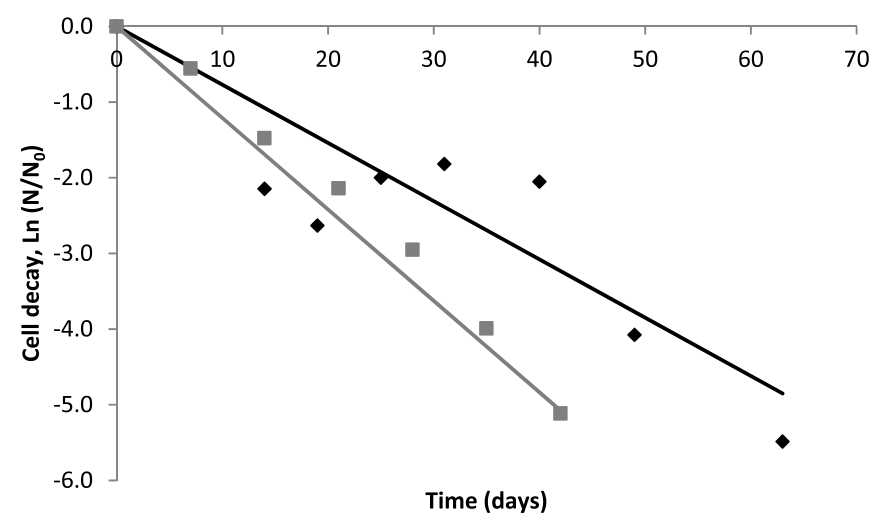

Fig. 4. L. casei cell decay ( $\mathrm{Ln} \mathrm{N} / \mathrm{N}_{0}$ ) along storage at $25^{\circ} \mathrm{C}$. Black rhomboids: okara ingredient; grey squares: EEM ingredient. Lines represent the respective fit to the first order kinetic. $\operatorname{Ln}\left(\frac{N}{N_{0}}\right)=-k_{d} \cdot t$

studied. L. casei presented immediate adaptation to the medium formulated with both soy by-products, growing with higher rate in okara. The process applied for homogenization and stabilising the final ingredient, reduced the $L$. casei 1.0 and $0.6 \log$ cycle for okara and EEM respectively. The ingredients could be safety stored without refrigerated storage; rendering a probiotic count above $10^{6} \mathrm{CFU} \mathrm{g} \mathrm{g}^{-1}$ at 63 and 42 days of storage for okara and EEM respectively. In view of the potential of these ingredients, mycotoxin level as well as urease activity should be controlled for a correct and safety application for human consumption, and it will be taken into account in future studies. Besides, with SSF process, almost all the soy by-products could be profited as raw material minimizing the generating of new wastes, fact that contribute to the circularity of the proposal.

\section{Funding}

This work was supported by Buenos Aires University (UBACyT; 2014-2017 20020130200237, 2018-2020 20020170100092), the National Agency of Scientific and Technical Research (PICT 2018-2021 3552); National Scientific Technical Research Council of Argentina (CONICET).

\section{Declaration of competing interest}

The authors have no Conflict of Interest to declare.

\section{CRediT authorship contribution statement}

Adriana P. Castellanos Fuentes: Investigation, Data curation, Formal analysis. Carolina E. Genevois: Methodology, Writing - review \& editing. Silvia K. Flores: Supervision, Writing - review \& editing, Visualization. Marina F. de Escalada Pla: Conceptualization, Writing original draft, Project administration.

\section{References}

Accoroni, C., Godoy, E., \& Reinheimer, M. A. (2020). Performance evaluation of protein recovery from Argentinian soybean extruded-expelled meals under different operating conditions. Journal of Food Engineering, 274(November 2019), Article 109849. https://doi.org/10.1016/j.jfoodeng.2019.109849.

Alvarez, M. M., Aguirre-Ezkauriatza, E. J., Ramírez-Medrano, A., \& RodríguezSánchez, Á. (2010). Kinetic analysis and mathematical modeling of growth and lactic acid production of Lactobacillus casei var. rhamnosus in milk whey. Journal of Dairy Science, 93(12), 5552-5560. https://doi.org/10.3168/jds.2010-3116.

AOAC (Association of Official Analytical Chemists). (2006). Official Method 920.152 and 960.39. Association of Official Analytical Chemists Methods. AOAC (18 th). Arlington: AOAC.

Champagne, C. P., Ross, R. P., Saarela, M., Hansen, K. F., \& Charalampopoulos, D. (2011). Recommendations for the viability assessment of probiotics as concentrated 
cultures and in food matrices. International Journal of Food Microbiology, 149(3), 185-193. https://doi.org/10.1016/j.ijfoodmicro.2011.07.005.

Costa, J. A. V., Treichel, H., Kumar, V., \& Pandey, A. (2018). Advances in solid-state fermentation. Current developments in biotechnology and bioengineering. Elsevier B.V. https://doi.org/10.1016/b978-0-444-63990-5.00001-3.

Couto, S. R., \& Sanromán, M.Á. (2006). Application of solid-state fermentation to food industry-A review. Journal of Food Engineering, 76(3), 291-302. https://doi.org/ 10.1016/j.jfoodeng.2005.05.022.

Genevois, C., Flores, S., \& de Escalada Pla, M. (2016). Byproduct from pumpkin (Cucurbita moschata Duchesne ex poiret) as a substrate and vegetable matrix to contain Lactobacillus casei. Journal of Functional Foods, 23, 210-219. https://doi. org/10.1016/j.jff.2016.02.030.

Gervais, P., \& Molin, P. (2003). The role of water in solid-state fermentation. Biochemical Engineering Journal, 13, 85-101.

Li, X. Y., Chen, X. G., Sun, Z. W., Park, H. J., \& Cha, D. S. (2011). Preparation of alginate/ chitosan/carboxymethyl chitosan complex microcapsules and application in Lactobacillus casei ATCC 393. Carbohydrate Polymers, 83(4), 1479-1485. https:// doi.org/10.1016/j.carbpol.2010.09.053.

Li, C., Li, W., Chen, X., Feng, M., Rui, X., Jiang, M., et al. (2014). Microbiological, physicochemical and rheological properties of fermented soymilk produced with exopolysaccharide (EPS) producing lactic acid bacteria strains. LebensmittelWissenschaft und -Technologie- Food Science and Technology, 57(2), 477-485. https:// doi.org/10.1016/j.lwt.2014.02.025.

Poletto, P., Polidoro, T. A., Zeni, M., \& da Silveira, M. M. (2017). Evaluation of the operating conditions for the solid-state production of pectinases by Aspergillus Niger in a bench-scale, intermittently agitated rotating drum bioreactor. LebensmittelWissenschaft und -Technologie- Food Science and Technology, 79, 92-101. https://doi. org/10.1016/j.lwt.2017.01.018.

Porfiri, M. C., Vaccaro, J., Stortz, C. A., Navarro, D. A., Wagner, J. R., \& Cabezas, D. M. (2017). Insoluble soybean polysaccharides: Obtaining and evaluation of their O/W emulsifying properties. Food Hydrocolloids, 73, 262-273. https://doi.org/10.1016/j. foodhyd.2017.06.034.

Quintana, G., Gerbino, E., \& Gómez-Zavaglia, A. (2017). Okara: A nutritionally valuable by-product able to stabilize lactobacillus plantarum during freeze-drying, spraydrying, and storage. Frontiers in Microbiology, 8(APR), 1-9. https://doi.org/10.3389/ fmicb.2017.00641.

Rezvani, F., Ardestani, F., \& Najafpour, G. (2017). Growth kinetic models of five species of Lactobacilli and lactose consumption in batch submerged culture. Brazilian Journal of Microbiology, 48(2), 251-258. https://doi.org/10.1016/j. bjm.2016.12.007.

Sharma, V., \& Mishra, H. N. (2014). Unstructured kinetic modeling of growth and lactic acid production by Lactobacillus plantarum NCDC 414 during fermentation of vegetable juices. Lebensmittel-Wissenschaft und -Technologie- Food Science and Technology, 59(2P1), 1123-1128. https://doi.org/10.1016/j.lwt.2014.05.039.

Tymczyszyn, E. E., Díaz, R., Pataro, A., Sandonato, N., Gómez-Zavaglia, A., \& Disalvo, E. A. (2008). Critical water activity for the preservation of Lactobacillus bulgaricus by vacuum drying. International Journal of Food Microbiology, 128(2), 342-347. https://doi.org/10.1016/j.ijfoodmicro.2008.09.009.

Vong, W. C., \& Liu, S. Q. (2016). Biovalorisation of okara (soybean residue) for food and nutrition. Trends in Food Science \& Technology, 52, 139-147. https://doi.org/ 10.1016/j.tifs.2016.04.011.

Vong, W. C., \& Liu, S. Q. (2019). The effects of carbohydrase, probiotic Lactobacillus paracasei and yeast Lindnera saturnus on the composition of a novel okara (soybean residue) functional beverage. Lebensmittel-Wissenschaft \& Technologie, 100(April 2018), 196-204. https://doi.org/10.1016/j.lwt.2018.10.059.

WHO/FAO. (2006). Probiotics in food: Health and nutritional properties and guidelines for evaluation.

Xu, M., Gagné-Bourque, F., Dumont, M. J., \& Jabaji, S. (2016). Encapsulation of Lactobacillus casei ATCC 393 cells and evaluation of their survival after freezedrying, storage and under gastrointestinal conditions. Journal of Food Engineering, 168, 52-59. https://doi.org/10.1016/j.jfoodeng.2015.07.021. 